\title{
Yield Response to Orange Cane Blotch of Blackberry Grown in the Georgia Coastal Plain
}

\author{
Frances B. Browne, ${ }^{1}$ Phillip M. Brannen, ${ }^{1,}$ Harald Scherm, ${ }^{1}$ Elizabeth A. Richardson, ${ }^{2}$ and Jeremy R. Taylor ${ }^{3}$ \\ ${ }^{1}$ Department of Plant Pathology, University of Georgia, Athens, GA 30602 \\ ${ }^{2}$ Georgia Electron Microscopy, University of Georgia, Athens, GA 30602 \\ ${ }^{3}$ University of Georgia Extension, Lakeland, GA 31635
}

\begin{abstract}
Orange cane blotch (OCB), an algal disease on commercial blackberry plants in the southeastern United States, has been an increasing concern among producers. The causal agent, Cephaleuros virescens, produces brightly colored green to orange lesions on blackberry stems, but proof of actual damage and impact on crop yield has not been documented. Naturally infected stem sections were viewed using transmission and

observed on the surface and epidermal layers. Field studies at four commercial sites over 2 years were conducted to assess the impact of OCB on yield in 'Ouachita' blackberry plants not treated with algicidal chemicals. Neither cane diameter nor berry size was impacted by severity of OCB; however, berry number decreased with increasing OCB intensity in a nonlinear manner, thereby resulting in reduced yields.
\end{abstract} scanning electron microscopy to evaluate cane damage. Surface abrasions, intercellular growth, and occasional intracellular growth were

Keywords: orange felt, parasitic algae, yield response

In recent years, breeding programs have released blackberry (Rubus fructicosus) cultivars adapted to warmer climates, allowing an increase in blackberry production in the southeastern United States, primarily in the Coastal Plain region. Traditional blackberry production areas do not experience such warm temperatures and high humidity as those observed in the southern states. As a result of these climatic conditions, cane diseases are a major concern for blackberry production in the Southeast. One disease in particular, orange cane blotch (OCB), has become prevalent in the Coastal Plain, causing great concern to producers. Commercial varieties have been selected largely based on consumer appeal; however, several of these cultivars are highly susceptible to $\mathrm{OCB}$.

OCB, also known as orange felt, is caused by the parasitic alga, Cephaleuros virescens Kunze. The alga is often mistaken for other disease-causing organisms due to the velvety appearance (Thompson and Wujek 1997). A Cephaleuros sp. was reported on blackberry stems in Florida in 1981 (Marlatt and Alfieri 1981). The species was not confirmed, but researchers speculated the alga could be found on a broad range of host plants in the Southeast. The first report of OCB on commercial blackberry was from Texarkana, AR, on a commonly planted cultivar, 'Navajo'. Reported symptoms and signs included stem cracks, discoloration of tissue, and velvet-like orange blotches on canes. Sporangiophores were reported as the source of the felt-like appearance. Zoospores were released when these reproductive structures were placed in water; however, the zoospores did not germinate in vitro, and pathogenicity was not confirmed (Holcomb 1986). A subsequent report involved blackberry canes at

${ }^{\dagger}$ Corresponding author: P. M. Brannen; pbrannen@uga.edu

Funding: This research was funded in part by the National Raspberry and Blackberry Association.

*The $\boldsymbol{e}$-Xtra logo stands for "electronic extra" and indicates that one supplementary table is published online.

The author(s) declare no conflict of interest.

Accepted for publication 23 July 2019.

C 2020 The American Phytopathological Society the Calhoun Research Station in northern Louisiana (Holcomb et al. 1998).

C. virescens thrives in warm, wet, and humid environments. Investigators initially believed that the alga was opportunistic and that heavy infection was limited to stressed plants (Thompson 1959). This assumption was likely due to the difficulty of growing and producing reproductive structures in vitro (Chapman and Good 1983; Holcomb et al. 1998). Although the pathogenic capability of $C$. virescens has been controversial, it has been hypothesized that algal infection can lead to girdling of canes and, in severe cases, cane decline and death (Chapman and Good 1983; Holcomb 1986; Holcomb et al. 1998). In some reports, the alga is considered an obligate epiphyte, while others characterize the species as an occasional or obligate parasite (Thompson and Wujek 1997). However, it is now apparent that several factors are involved in host specificity (Chapman and Good 1983) and environmental interactions. Various Cephaleuros spp. can differ in their growth habit when observed on different host plants. Some species exhibit intercellular growth, while others, such as $C$. virescens, have been characterized as a subcuticular species (Guiry and Guiry 2019).

C. virescens has been known to tropical agriculture for many years (Brooks et al. 2015). Indeed, the alga is capable of infecting nearly 300 vascular plant species in 53 different families (Holcomb 1986), and infection of 115 plant species has been recorded in Louisiana alone (Holcomb 1975). Host compatibility is likely due to factors such as cuticle thickness, host response, and surface topography (Chapman and Good 1983). Various organs, to include fruits, stems, and leaves, are infected (Marlatt and Alfieri 1981). At least 80 host relations were stem invasions similar to those observed on blackberry canes. Stem infections are considered more detrimental to the plant, because translocation of nutrients could be hindered, and partial or total girdling of the cane is possible (Chapman and Good 1983). Resulting downstream effects for the host plant could include a decrease in the number of leaves or reproductive structures, stunted plants, or even plant death.

Epidemiological knowledge is limited for diseases incited by $C$. virescens; however, it is assumed that plants are damaged directly by the alga (Holcomb et al. 1998). Infections by C. virescens in other plant species demonstrate an invasion of the space between the epidermal cells underneath the cuticle, causing damage near the plant surface (Suto et al. 2014). This particular growth pattern could be responsible for the typical cracking of blackberry canes 
observed in the field. A major concern with cracked tissues caused by OCB is potential invasion by other cane pathogens. When favorable conditions persist in the field, a combination of substantial algal colonization and presence of detrimental secondary infections could result in death and dieback of canes (Brooks 2004). Ramya and Ponmurugan (2012) reported decreased transpiration, photosynthetic rate, and stomatal conductance in tea

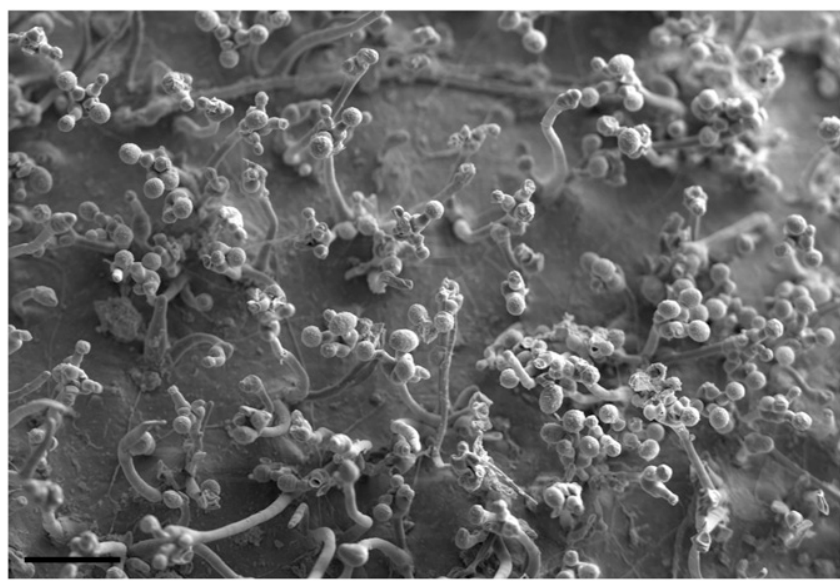

Fig. 1. Scanning electron micrograph of sporulating algal lesion on infected blackberry cane showing sporangiophores of Cephaleuros virescens emerging from the affected tissue. Each sporangiophore bears multiple sporangia. Scale bar $=100 \mu \mathrm{m}$.

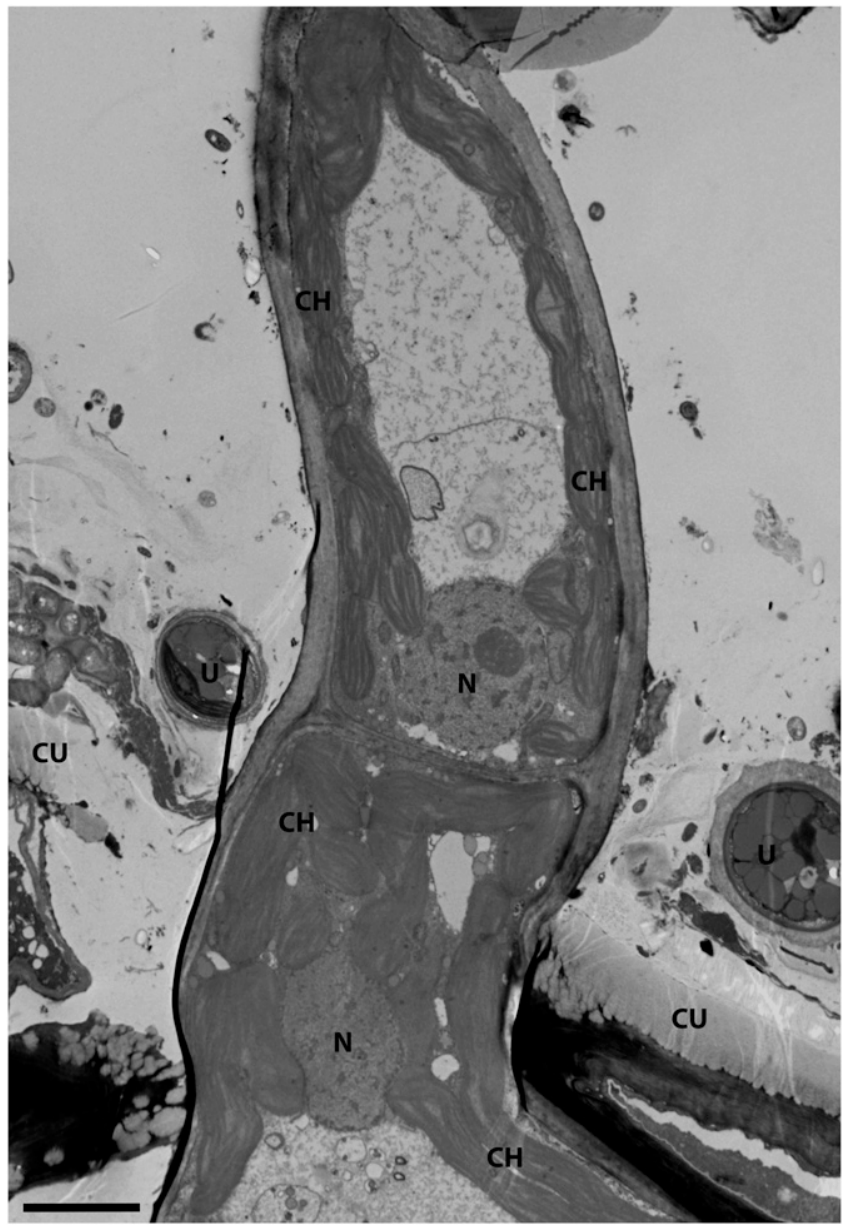

Fig. 2. Transmission electron micrograph of a Cephaleuros virescens sporangiophore emerging from an infected blackberry cane, causing a break in the cane surface and cuticle (CU). The sporangiophore shows clearly defined chloroplasts $(\mathrm{CH})$ and nuclei (N). Unidentified organisms $(U)$ are located near the cuticle break. Scale bar $=4 \mu \mathrm{m}$. plants infected by subaerial algae (algae growing above ground and exposed to air). Reduced pigments, sugar, nitrogen, amino acids, and other biochemical constituents were also observed for infected plants.

In the field, stem lesions of OCB on blackberry appear in late summer or early fall and may increase in size throughout the fall, winter, and spring of the following year. Primocanes (initial vegetative canes) emerge in late spring during the time algal lesions begin to sporulate on the floricanes (flower and fruit-bearing canes). Sporangiophores emerge from the cane surface, each containing several zoosporangia. During moist conditions, the zoosporangia abscise, and zoospores contained inside are released and likely spread from floricanes to new primocanes during this timeframe (Suto and Ohtani 2013). Hence, old floricanes should be removed and destroyed immediately after harvest as a cultural disease management task (Brannen 2018; Brannen et al. 2019). Reproduction in Cephaleuros algae has been described as an alternation of heteromorphic generations with homothallic mating, a system similar to that of land plants (Thompson 1959; Thompson and Wujek 1997). While the life cycle of Cephaleuros algae has been reported in general terms, the biennial growth pattern of blackberries may further complicate the disease cycle.

Additional recommendations for OCB management include strategic site drainage and appropriate row bedding, selective pruning to increase air movement in the canopy, effective weed control, use of plastic mulch in combination with drip irrigation, and application of agrichemicals with activity against algae (Brannen 2018; Brannen et al. 2019). While control measures have been recommended, the yield impact of OCB has not been studied previously. The objectives of this study are, therefore, to investigate the intensity of damage on diseased canes and to assess yield losses due to $\mathrm{OCB}$.

\section{Materials and Methods}

Observation of cane damage by SEM and TEM. Field samples of symptomatic canes were collected from Berrien, Clinch, and Lanier counties in southern Georgia for microscopic examination of cane damage through electron microscopy (EM). A sterile razor blade was used to cut thin cross-sections of infected canes in the field, and these were immediately placed in a fixative (5\% EM grade glutaraldehyde and potassium phosphate buffer) to prevent degradation of materials. Samples were then submitted to the Georgia Electron Microscopy facility at the University of Georgia for further processing.

Some tissues were processed following a standard chemical fixation protocol in preparation for scanning electron microscopy (SEM) (Glidewell and Mims 1979; Mims 1981). Tissue was fixed overnight at $4{ }^{\circ} \mathrm{C}$ in a $1: 1$ mixture of $5 \% \mathrm{EM}$ grade glutaraldehyde and $0.1 \mathrm{M}$ potassium phosphate buffer ( $\mathrm{pH} 6.8$ or 7.2 ), followed by washing 3 times for $15 \mathrm{~min}$ in potassium phosphate buffer at $4^{\circ} \mathrm{C}$. A postfix mixture of $1: 12 \%$ osmium tetroxide and buffer was subsequently applied for $2 \mathrm{~h}$ at $4^{\circ} \mathrm{C}$. Samples were washed twice in double-distilled water $\left(\mathrm{ddH}_{2} \mathrm{O}\right)$ for $15 \mathrm{~min}$ each at $25^{\circ} \mathrm{C}$. Next, the samples were dehydrated using a graded ethanol series $(10,25,50,75,95,100$, and $100 \%$ ), each step requiring $15 \mathrm{~min}$. Samples were then critical point-dried and placed into a desiccator before being mounted on stubs and stored in the desiccator again. Samples were coated with gold palladium and stored in the desiccator for future use. Samples were viewed on an SEM (Zeiss 1450EP, Carl Zeiss MicroImaging, Thornwood, NY) at $15 \mathrm{kV}$.

Additional samples were processed using a transmission electron microscopy (TEM) protocol (Glidewell and Mims 1979; Mims 1981) for plant material using Spurr's resin. Samples were fixed overnight in $5 \%$ (vol/vol) glutaraldehyde and potassium phosphate buffer $(\mathrm{pH} 7.2)$ at $4^{\circ} \mathrm{C}$. Samples were then washed in potassium phosphate buffer 2 or 3 times each for $15 \mathrm{~min}$ at $4^{\circ} \mathrm{C}$. Next, samples were stained in $2 \%$ (vol/vol) $\mathrm{OsO}_{4}$ for $2 \mathrm{~h}$ at $4^{\circ} \mathrm{C}$. Distilled water $\left(\mathrm{dH}_{2} \mathrm{O}\right)$ was used to rinse the samples twice for $15 \mathrm{~min}$ each at room temperature. Aqueous uranyl acetate $(0.5 \%)$ was used for en bloc staining overnight before rinsing with $\mathrm{ddH}_{2} \mathrm{O}$ twice for $15 \mathrm{~min}$ 
each. Dehydration steps were carried out next, using a series of graded ethanol $(25,50,75,95$, and $100 \%)$ concentrations for 15 min each. Samples were incubated in acetone and Spurr's resin for $8 \mathrm{~h}$ in each of the following steps: 1) $75 \%$ acetone and $25 \%$ Spurr's, 2) 50\% acetone and 50\% Spurr's, 3) $75 \%$ acetone and $25 \%$ Spurr's, 4) 100\% Spurr's, and 5) 100\% Spurr's. Next, samples were embedded in Permanox petri dishes and allowed to rest in molds for $45 \mathrm{~min}$. Molds were then placed in an oven for polymerization at $60^{\circ} \mathrm{C}$ for $24 \mathrm{~h}$. Blocks were trimmed with razor blades, and $70-\mathrm{nm}$ sections were cut with a Diatome diamond knife on a Reichert-Jung ultramicrotome and placed on grids before staining with uranyl acetate and lead citrate. The grids were viewed with a transmission electron microscope (JEOL JEM 1011, Tokyo, Japan). Thick sections $(1 \mu \mathrm{m})$ were cut and stained with $1 \%$ toluidine-blue for light microscopy.

OCB impact on blackberry yield. Disease progression was assessed in the spring of 2015 over a 3-month period at three commercial blackberry sites in Berrien, Echols, and Lanier counties (one site per county) in southern Georgia. The popular blackberry cultivar 'Ouachita' was used for disease progress trials. Mature plants ( $\sim 6$ years old) remained unsprayed for field studies. Onehundred primocanes were marked with field tape at all locations and assessed throughout the season. Percent algal cane coverage was estimated visually for the entire length of cane, viewed from each adjacent row middle (average of two observations per cane) at five dates as follows: Berrien County - 19 March, 3 April, 17 April, 30 April, and 11 May; Echols County - 20 March, 2 April, 17 April, 30 April, and 15 May; Lanier County - 20 March, 3 April, 17
April, 30 April, and 14 May. On the same day as the last assessment, blackberry fruit were harvested from each marked cane while still red in color, and cane diameters were recorded using digital calipers (Mitutoyo, Aurora, IL). Berries were counted and total berry weight per cane was measured with a digital balance (Ohaus, Parsippany, $\mathrm{NJ}$ ).

A similar method was used to assess disease progression in the following growing season, but disease assessments were initiated in the fall of 2015 and continued through the spring of 2016 in Berrien, Clinch, and Lanier counties (one site per county). Again, 100 canes of relatively uniform size were selected at each site and algal coverage was assessed (as percent cane coverage with symptoms) throughout the growing season. Marked canes were assessed on dates as follows: Berrien County - 19 October and 9 November 2015 and 5 January, 13 March, 29 April, and 18 May 2016; Clinch County - 9 November 2015 and 5 January, 11 March, 29 April, and 17 May 2016; Lanier County - 16 October and 6 November 2015 and 5 January, 11 March, 29 April, and 16 May 2016. As in the previous crop year, cane diameters were measured, and berries were removed from marked canes on the last assessment date (a few weeks before commercial harvest); yield was quantified by recording berry numbers and weight, all as described previously.

Data analysis. Using the method of trapezoidal integration (Campbell and Madden 1990), cane disease severity values over time were converted to areas under the disease progress curve (AUDPC), in units of percent-days, for all trials. Linear correlations among berry number, total berry weight per cane, cane diameter, and AUDPC were calculated in SigmaPlot v. 11.0 (Systat Software, San Jose,

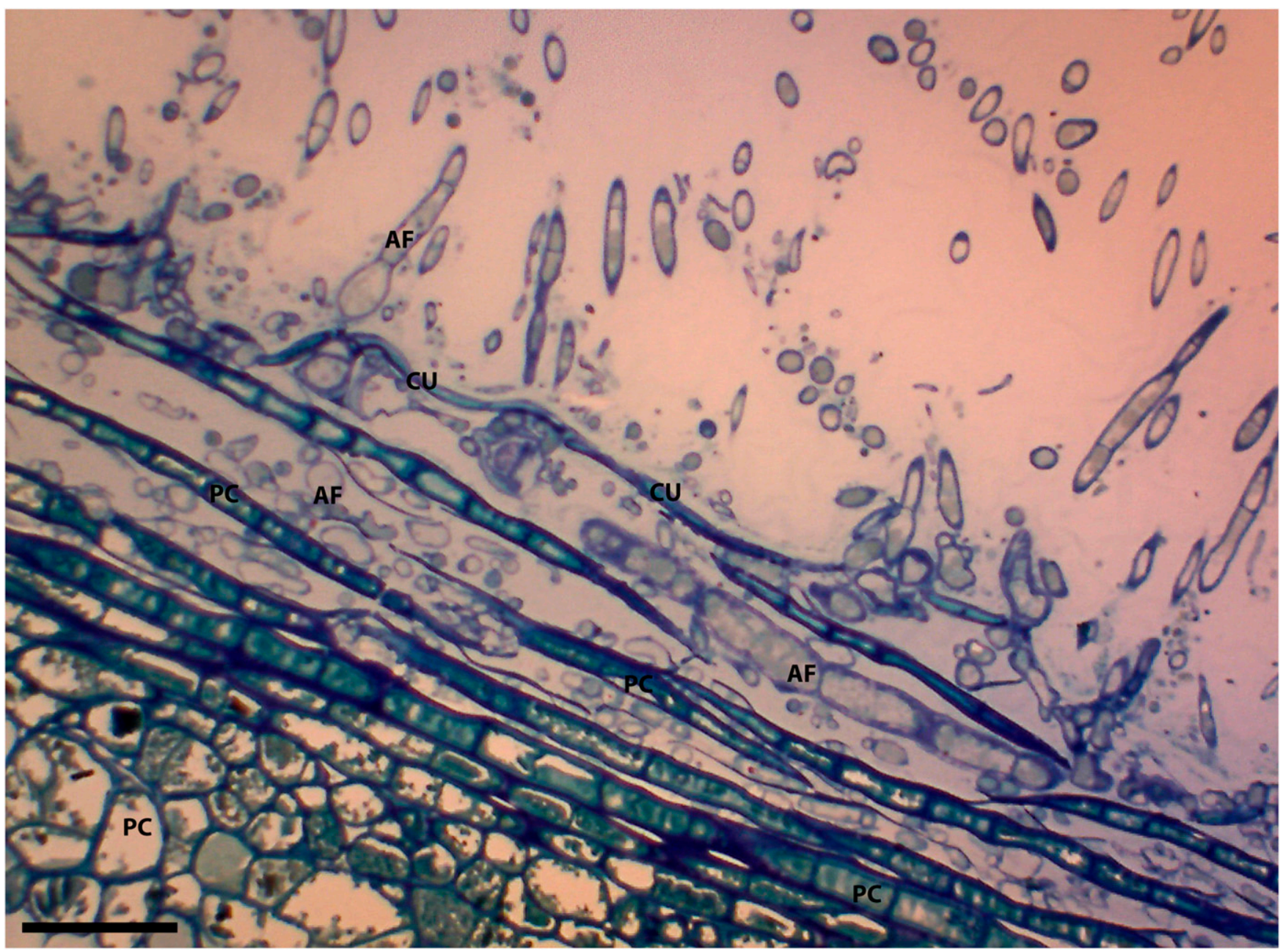

Fig. 3. Light micrograph of blackberry cane surface infected by Cephaleuros virescens. Algal filaments grow intercellularly, disrupting layers of plant epidermal tissue. AF, algal filament; CU, plant cuticle; PC, plant cells; scale bar $=20 \mu \mathrm{m}$. 
CA). Berry numbers and total berry weight per cane were plotted against AUDPC or AUDPC divided by cane cross-sectional area; the latter conversion was done as a means of standardization to account for potential effects of cane cross-sectional area on yield (Archbold et al. 1989). Nonlinear regression analysis (SigmaPlot v. 11.0) was used to explore the relationship between the number of berries and AUDPC per cane cross-sectional area using an inverse first-order polynomial. Since total berry weight per cane and berry numbers were closely correlated (with $r$ values ranging from 0.89 to 0.96 ; Supplementary Table $\mathrm{S} 1$ ), only berry numbers were analyzed. Statistical significance was assessed at $P \leq 0.05$.

\section{Results}

Observation of cane damage by SEM and TEM. Electron microscopy demonstrated the extent of algal colonization of infected canes. Algal filaments under the surface gave rise to large numbers of fertile erect branches that penetrated the blackberry cane surface causing microabrasions over large areas (Fig. 1). Figure 2 shows a single sporangiophore breaking through the surface, creating a small wound. All cells of algal origin (sterile and fertile branches) contained intact chloroplasts with thylakoid membranes. Fertile branches compromised the integrity of the protective waxy layer on the blackberry surface. A build-up of additional organisms of unknown origin was noted at several locations at breaks where sporangiophores pushed through the surface (Fig. 2). Intercellular growth of algal filaments was observed in infected canes (Figs. 3 and 4). Algal filaments grew between plant cells, breaking apart whole layers of epidermal tissue. Whole plant cells were completely surrounded by algal filaments that altered the natural orientation of plant tissue. Intracellular algal growth was also observed (Fig. 5A-C). Invading algal cells with clearly defined chloroplasts were documented growing inside of host plant cells encompassed by external filaments.

OCB impact on blackberry yield. Correlations of total berry number per cane, individual berry weight, or stem cross-sectional area with AUDPC across the six trials were inconsistent (Table 1). Although models were occasionally significant, correlation coefficients were low, indicating a weak relationship. However, significant nonlinear relationships $(P<0.05)$ emerged in all but one location when berry number per cane was regressed against AUDPC divided by cane cross-sectional area (Fig. 6).

Disease severity varied considerably among locations, even within the same year. For example, in 2015, disease severity was substantively higher in Echols than in Lanier and Berrien counties (Fig. 6A, C, and E). Nevertheless, all test sites demonstrated decreased yield (number of berries per cane) with increasing disease levels (AUDPC per cane cross-sectional area) without regard to disease pressure. In 2015, correlation coefficients of nonlinear regression were low, ranging from 0.35 to 0.42 , but $P$ values ranged from 0.0001 to 0.0004 . Similar results were observed in Berrien and Clinch counties in 2016 (Fig. 6B and D), whereas the data collected in Lanier County showed no significant relationship between berry number per cane and AUDPC per cane cross-sectional area (Fig. $6 \mathrm{~F}$ ); this was the only location among the six field assessments that did not show a significant relationship between disease and blackberry yield.

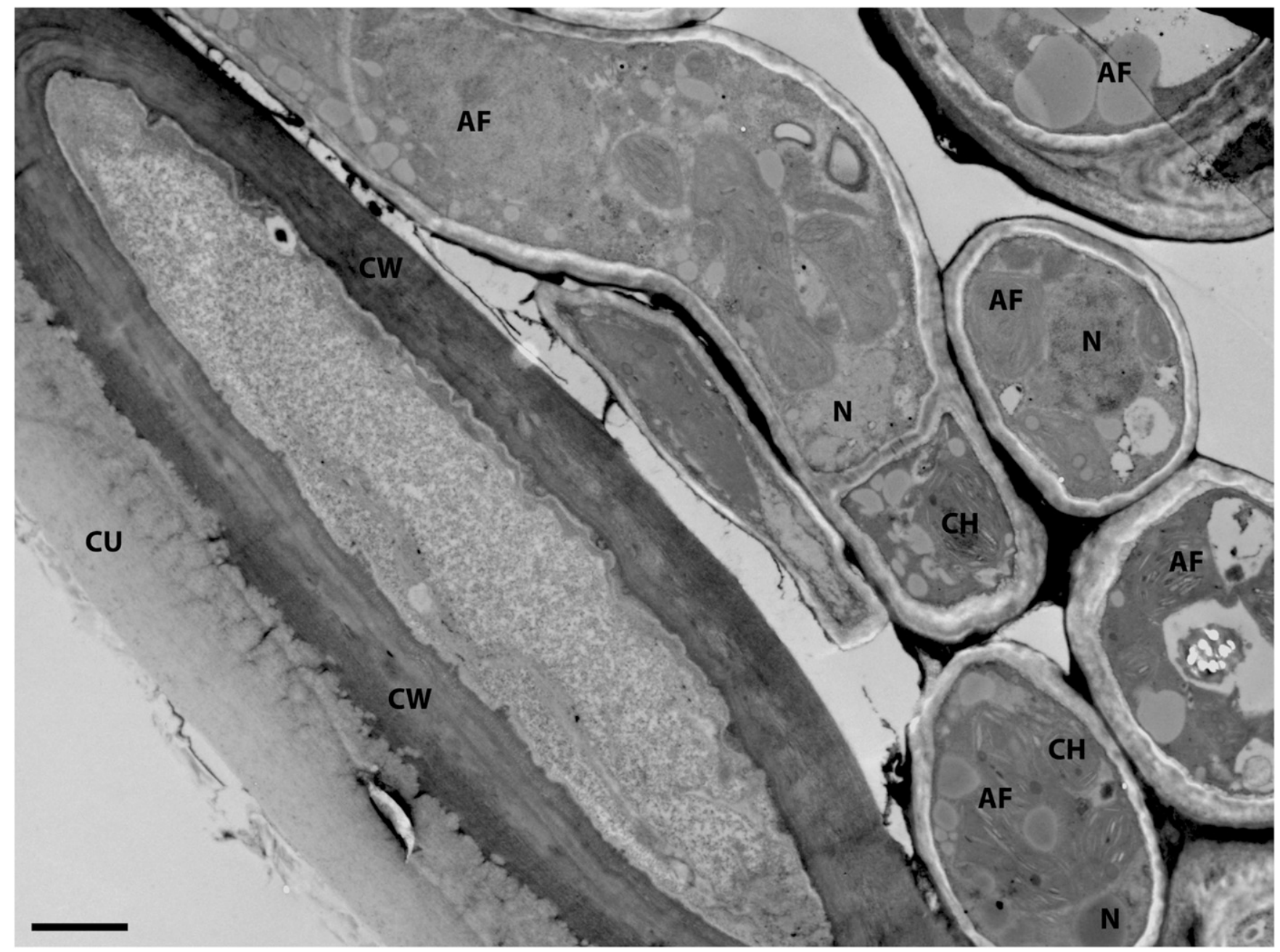

Fig. 4. Transmission electron micrograph demonstrating intercellular growth of Cephaleuros virescens in a blackberry cane. Algal filaments grow between host plant cells, causing physical damage. AF, algal filament; $\mathrm{CH}$, algal chloroplast; $\mathrm{CU}$, plant cuticle; $\mathrm{CW}$, plant cell wall; $\mathrm{N}$, algal nucleus. Scale $=2 \mu \mathrm{m}$. 


\section{Discussion}

Plant-pathogenicity of algal species has been a subject of considerable controversy. In the past, actual damage caused by algal infections has not been clearly documented, especially in the case of stem infections. Previous investigators believed that Cephaleuros algae were opportunistic pathogens, and severe infections were observed only on stressed plants (Thompson 1959); however, infections on blackberry canes in the southeastern United States appear evenly dispersed in fields, suggesting that algal infection is more dependent on environmental conditions than on plant stress.

Previously, little was known about the pathogenesis of OCB on blackberry, but it was assumed that the alga could damage plants directly (Holcomb et al. 1998). During sporulation, large numbers of sporangiophores erupt through the surface of canes, and each fertile branch makes its own tear in the protective waxy cuticle, creating a wound. In addition, this study also confirmed the intercellular growth of algal filaments, similar to that observed with algal diseases reported in other plant species (Suto et al. 2014). This intercellular growth separates epidermal layers near the surface, compromising tissue structure.

In addition to intercellular growth, the alga may also be capable of intracellular growth, a growth habit that has not been clearly observed in algal systems. Electron micrographs obtained in this study showed invasion of plant cells by structures having chloroplasts with thylakoid membranes and presumed to be of algal origin. Although host plant cells appear to be invaded by algal filaments, it cannot be determined whether the alga directly penetrates host cells or only invades after host cells are compromised. In the latter scenario, algal filaments may only be able to invade weakened host cells.

Plant diseases involving infection of young stems could result in partial or complete girdling of the cane and impairment of nutrient translocation (Chapman and Good 1983). Based on the growth patterns observed in this study, algal filaments appear to have the ability to grow in the intercellular spaces around the entire cane surface. Heavy infection observed at the base of canes may be a result of zoospores being washed down toward the ground. These heavily infected areas are of particular concern because the pathogen may girdle the cane in an area that would impact main and lateral shoots from which flowers and fruit arise. Girdled stems and stunting, followed by death and dieback of stems, has been frequently associated with Cephaleuros infections (Chapman and Good 1983; Holcomb 1986; Holcomb et al. 1998; McMillan 1976). In this context, one would expect the disease to influence yield.

Disease severity and berry yield varied among locations and years in field studies. Variable disease pressure could result from environmental differences such as rainfall. In addition, lack of proper management in previous years could impact disease levels. Sporulating algal lesions are present on floricanes, from which inoculum infects primocanes that produce the blackberry crop for the following year; therefore, if the disease is not adequately controlled in the previous year, the subsequent crop may have more severe disease levels. Berry numbers also varied from year to year, likely due to environmental differences. For example, blackberry yield is highly dependent on temperature during bud formation, and buds can be killed when temperatures drop below $-2^{\circ} \mathrm{C}$ (Krewer et al. 1999). Despite the variability observed in disease levels and yields, results were obtained that clearly tied increasing OCB disease intensity with decreased berry yield.

For both Clinch and Lanier counties in 2016, berry weight and number were correlated with AUDPC (Table 1), but other locations showed no correlation between berry number or weight and AUDPC, indicating that linear relationships are inconsistent. However, when AUDPC was standardized by dividing by the cane cross-sectional area (Archbold et al. 1989), the most consistent relationship was nonlinear, and it was observed when relating blackberry yield (number of berries per cane) to cumulative orange blotch severity divided by the cane cross-sectional area. Using this relationship, yield was significantly impacted by OCB in 5 out of 6 locations assessed (Fig. 6). Decreased total berry weight per cane corresponded to a decreased number of berries per cane; a pattern that was consistent under varying disease levels. Berry numbers and total berry weight per cane were highly correlated, indicating either variable is sufficient as a measurement of yield.

Cane diameter was not affected by OCB levels in 5 of the 6 sites (Table 1), suggesting that cane development was not consistently

Table 1. Correlation coefficients $(r)$ and probability values $(P)$ for the association of cumulative orange cane blotch severity (area under the disease progress curve) with the yield variables berry number per cane, total berry weight per cane, and stem cross-sectional area on blackberry in six trials in southern Georgia, 2015 and 2016

\begin{tabular}{|c|c|c|c|c|c|c|}
\hline \multirow[b]{2}{*}{ Site and year } & \multicolumn{2}{|c|}{ Berry number } & \multicolumn{2}{|c|}{ Berry weight (g) } & \multicolumn{2}{|c|}{$\begin{array}{c}\text { Stem } \\
\text { cross-sectional } \\
\text { area }\left(\mathbf{c m}^{2}\right)\end{array}$} \\
\hline & $r$ & $P$ & $r$ & $P$ & $r$ & $P$ \\
\hline \multicolumn{7}{|l|}{2015} \\
\hline Berrien & 0.1202 & 0.2385 & 0.1339 & 0.1886 & 0.0704 & 0.4911 \\
\hline Echols & 0.0708 & 0.5027 & 0.0078 & 0.9413 & 0.0496 & 0.6386 \\
\hline Lanier & 0.0582 & 0.5672 & 0.0930 & 0.3599 & 0.0722 & 0.4774 \\
\hline \multicolumn{7}{|l|}{2016} \\
\hline Berrien & 0.0004 & 0.9971 & 0.0607 & 0.5524 & 0.1225 & 0.2294 \\
\hline Clinch & 0.4415 & $<0.0001$ & 0.3759 & 0.0001 & 0.3983 & $<0.0001$ \\
\hline Lanier & 0.4667 & $<0.0001$ & 0.4383 & $<0.0001$ & 0.0423 & 0.6776 \\
\hline
\end{tabular}
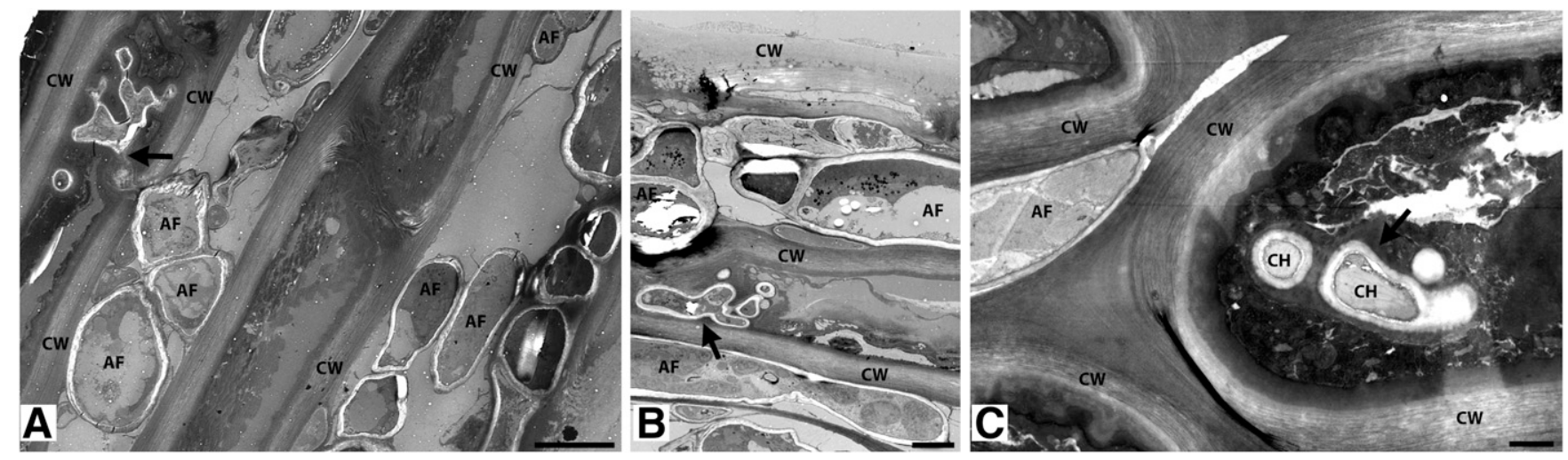

Fig. 5. Transmission electron micrographs of intracellular growth of Cephaleuros virescens (arrows) inside blackberry cane cells in several stem sections (A, B, C). Invading cells show clearly defined algal chloroplasts in C (arrow). AF, algal filament; CW, plant cell wall; $\mathrm{CH}$, algal chloroplast. Scale bar (right corner) $=6,4$, and $1 \mu \mathrm{m}$ for A, B, and C, respectively. 
impacted by disease. The Clinch County site in 2016, however, did show a relationship between cane diameter and disease. This could be a result of higher disease levels than that observed at other locations, but it could also be a result of random variability.

Our results show that OCB is a damaging disease of blackberries in the southeastern United States. Cane damage (surface and internal) was clearly recorded via light and electron microscopy. Although inter- and intracellular growth of algal filaments was also observed, it is not clear whether $C$. virescens is directly penetrating plant cells-requiring additional studies on damage mechanisms. A negative impact of increasing disease severity on yield was demonstrated, but more research should be conducted on the epidemiology of this disease. Producers can suppress OCB with potassium phosphite applications (Browne et al. 2016, 2019), and the relationship between potassium phosphite disease management and yield should also be examined in future studies.
A

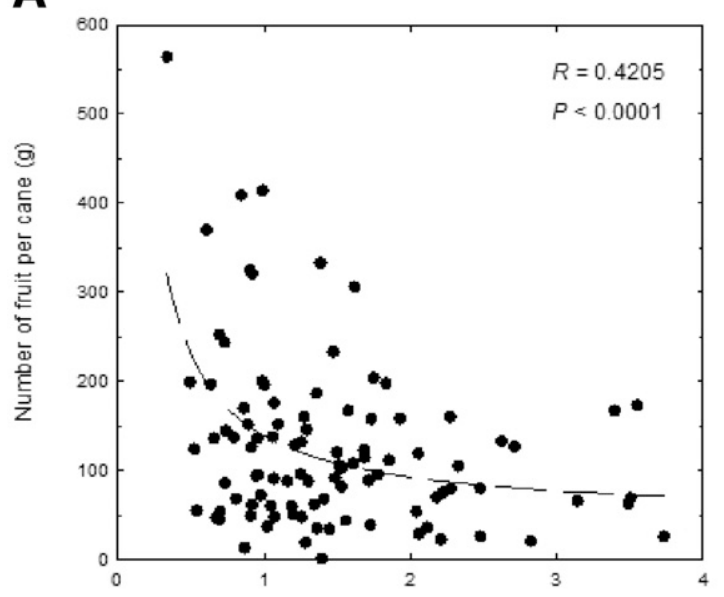

C

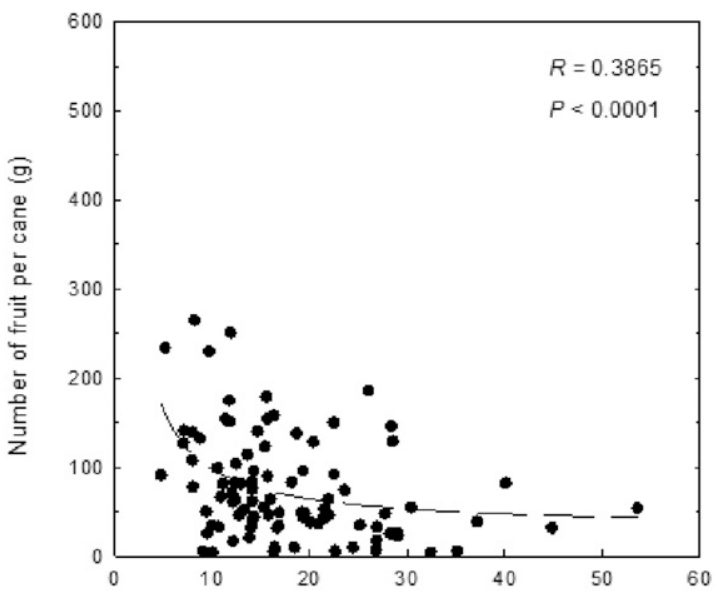

E

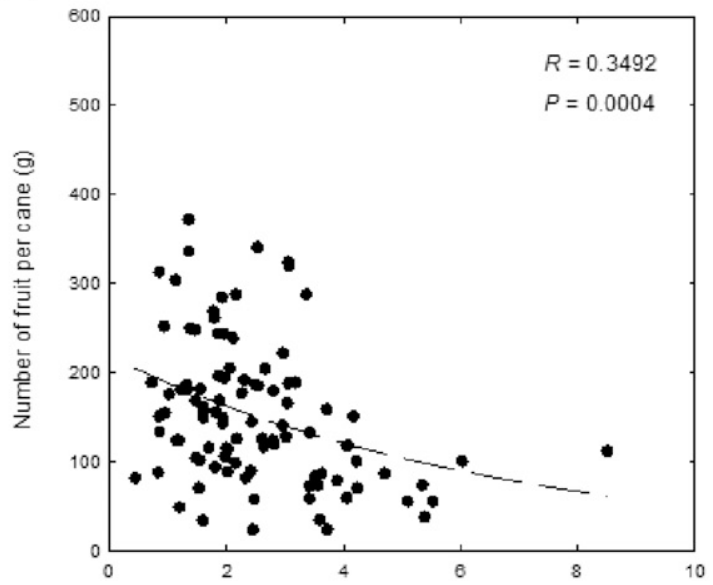

AUDPC/cane cross-sectional area (percent-day $/ \mathrm{cm}^{2}$ )
B Berrien County 2016

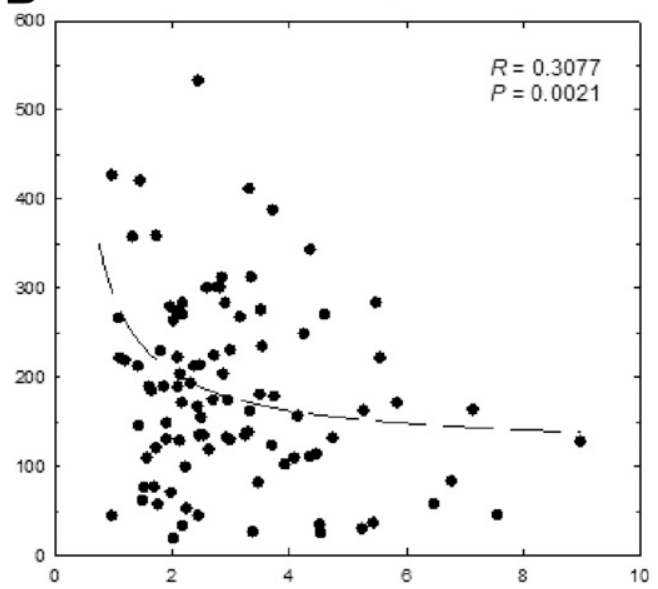

D Clinch County 2016

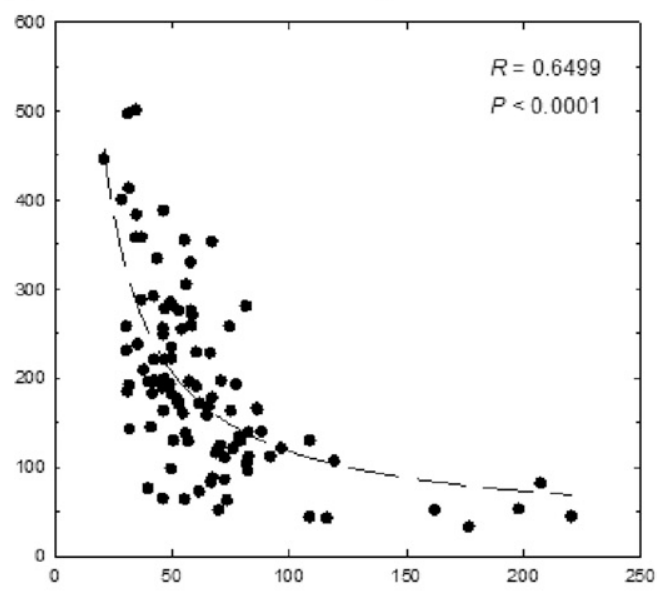

F Lanier County 2016

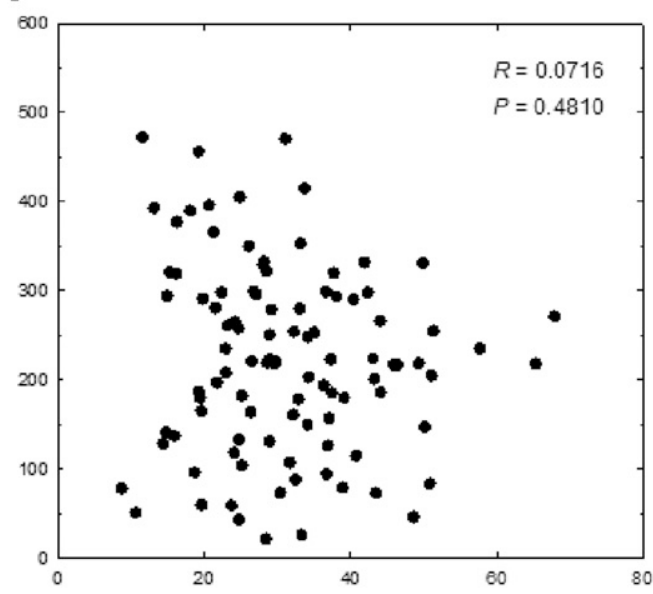

AUDPC/cane cross-sectional area (percent-day $/ \mathrm{cm}^{2}$ )

Fig. 6. Scatter plots relating blackberry yield (number of fruit per cane) to cumulative orange cane blotch severity divided by cane cross-sectional area (AUDPC/cane area) in six field trials in southern Georgia. Data from Berrien County $(\mathbf{A}, \mathbf{B})$, Echols County $(\mathbf{C})$, Clinch County (D), and Lanier County $(\mathbf{E}, \mathbf{F})$. The $r$ and $P$ values are from nonlinear regression analysis (inverse first-order polynomial). 


\section{Acknowledgments}

We thank the commercial blackberry growers and University of Georgia Extension agents who participated in this study.

\section{Literature Cited}

Archbold, D. D., Strang, J. G., and Hines, D. M. 1989. Yield component responses of 'Hull Thornless' blackberry to nitrogen and mulch. HortScience 24:604-607.

Brannen, P., Schnabel, G., Burrack, H., Bessin, R., Pfeiffer, D. G., Mitchem, W., Jennings, K., Lockwood, D., Fernandez, G., and Sial, A. 2019. 2019 Southeast Regional Caneberries Integrated Management Guide. Bull. 47. University of Georgia, Athens.

Brannen, P. M. 2018. Orange Felt (Orange Cane Blotch) of Blackberry. Ext. Circ. 892. University of Georgia, Athens.

Brooks, F. E. 2004. Plant-parasitic algae (Chlorophyta: Trentepohliales) in American Samoa. Pac. Sci. 58:419-428.

Brooks, F., Rindi, F., Suto, Y., Ohtani, S., and Green, M. 2015. The Trentepohliales (Ulvophyceae, Chlorophyta): an unusual algal order and its novel plant pathogen -Cephaleuros. Plant Dis. 99:740-753.

Browne, F. B., Brannen, P. M., Scherm, H., Taylor, J. R., Shealey, J. S., Fall, L. A., and Beasley, E. D. 2019. Evaluation of disinfectants, algicides, and fungicides for control of orange cane blotch of blackberry in the field. Crop Prot. 122:112-117.

Browne, F. B., Fall, L. A., Brannen, P. M., Taylor, J., Shealey, J., and Beasley, E. D. 2016. Assessment of algicides, disinfectants and fungicides for control of orange cane blotch caused by the alga Cephaleuros virescens. Acta Hortic.: 497-502

Campbell, C. L., and Madden, L. V. 1990. Introduction to Plant Disease Epidemiology. Wiley, New York.

Chapman, R. L., and Good, B. H. 1983. Subaerial symbiotic green algae: Interactions with vascular plant hosts (Phycopeltis, Stomatochroon, Trentepohlia). Pages 173-204 in: Algal Symbiosis: A Continuum of Interaction Strategies. L. J. Goff, ed. Cambridge University Press, Cambridge.

Glidewell, D. C., and Mims, C. W. 1979. Ultrastructure of the haustorial apparatus in the rust fungus Kunkelia nitens. Bot. Gaz. 140:148-152.
Guiry, M. D., and Guiry, G. M. 2019. AlgaeBase. World-wide electronic publication. National University of Ireland, Galway. http://www.algaebase.org, accessed on 02 June 2019

Holcomb, G. E. 1975. Hosts of the alga Cephaleuros virescens in Louisiana. Ann. Proc. Am. Phytopathol. Soc. 2:134.

Holcomb, G. E. 1986. Hosts of the parasitic alga Cephaleuros virescens in Louisiana and new host records for the continental United States. Plant Dis. 70:1080-1083.

Holcomb, G. E., Vann, S. R., and Buckley, J. B. 1998. First report of Cephaleuros virescens in Arkansas and it occurrence in cultivated blackberry in Arkansas and Louisiana. Plant Dis. 82:263.

Krewer, G., Smith, B., Brannen, P., and Horton, D. 1999. Commercial Bramble Culture. Bull. 964. University of Georgia, Athens.

Marlatt, R. B., and Alfieri, S. A., Jr. 1981. Hosts of Cephaleuros, a parasitic alga in Florida. Proc. Fla. State Hortic. Soc. 94:311-317.

McMillan, R. T., Jr. 1976. Diseases of avocado. Pages 66-70 in: Proceedings of the First International Tropical Fruit Short Course. J. W. Phillips, R. L. Jackson, and L. K. Sauls, eds. University of Florida, Gainesville.

Mims, C. W. 1981. SEM of aeciospore formation in Puccinia bolleyana. Scan. Electron Microsc. 3:299-303.

Ramya, M., and Ponmurugan, P. 2012. Host-pathogen interaction studies between susceptible and tolerant tea clones in relation to red rust disease. Int. J. Algae 14: 380-389.

Suto, Y., Ganesan, E. K., and West, J. A. 2014. Comparative observations on Cephaleuros parasiticus and C. virescens (Trentepohliaceae, Chlorophyta) from India. Algae 29:121-126.

Suto, Y., and Ohtani, S. 2013. Seasonal development of five Cephaleuros species (Trentepohliaceae, Chlorophyta) on the leaves of woody plants and the behaviors of their gametes and zoospores. Phycol. Res. 61:105-115.

Thompson, R. H. 1959. The life cycles of Cephaleuros and Stomatochroon. Page 397 in: Proceedings of the Ninth International Botanical Congress, vol. 2, University of Toronto Press.

Thompson, R. H., and Wujek, D. E. 1997. Trentepohliales: Cephaleuros, Phycopeltis, and Stomatochroon: Morphology, Taxonomy, and Ecology. Science Publishers, Enfield, NH. 